Аосова С.Н., Камбаров Б.К., Шоинжанова М.Т.

Аудармадағы баламалық мәсекекері

Dossova S.N., Kambarov B.K., Shoinzhanova M.

\section{Equivalence issues in translation}

Аосова С.Н., Камбаров Б.К., Шоинжанова М.Т.

Проблемы эквивалентности в переводе
Баламалық аударма ұлттық-тарихи, мәдени-тұрмыстық идеологиялық фракторларда маңызды орын алып, із қалдырды. Аударманың түпнұсқалық көркемдік жағын дұрыс жеткізу, яғни аудармашы туынАының образдық әлемін, автордың идеясын, позициясын және сти^ін нақты дәл көрсетуді қазіргі кезде аудару дәлдігі әртүрлі аудармамық, бағытта зерттелуде.

Бұл мақаяада аударманың балама түрі қазақ, орыс және шет елдер зерттеуші ғалымдарының бұл түсінікке берген анықтамалары қарастырылады. Аударма әрбір ұлттық мәдениеттің ажырамас бөлігі болып табылады. Баламалық аудару мәселесін филологтар зерттегеніне де біраз уақыт болды. Қазіргі кезде бұл мәселе әртүрлі аудармамық, бағытта шешімін табуда.

Түйін сөздер: аударма, балама, түпнұсқа.

This article deals with key issues of translation equivalence and different approaches of Kazakh, Russian and foreign scientists to define it.

Key words: equivalence, translation, target language.

В Аанной статье рассматриваются вопросы эквивалентности перевода и проводится анализ различных подходов к изучению эквивалентности перевода казахстанскими, российскими и зарубежными авторами.

Кмючевые слова: перевод, эквивалентность, оригинал. 


\section{АУААРМАААҒЫ БАААМААЫҚ MӘCEАEАEPI}

Баламалық термині қазіргі аударма теориясында кеңінен қолданылуда. П.М. Топер пікірлердің көп қырлылығын зерттеп, аудару теориясына «баламалық» терминінің қашан және қайдан кіргенін анықтады. «Алғаш рет «баламалық» терминін «Аударманың лингвистикалық аспектілері» туралы мақаласында Р. Якобсон ұсынған еді» [2].

Сонымен аударма баламалылығы - формалды сәйкестік немесе мағыналардың теңдігі дегенді білдірмейді. Баламалылықтың негізгі шарты ретінде Дж. Кэтфорд нақты бір жағдайда олардың бірін-бірі ауыстыра алуы деп есептейді. Бұдан шығатын қорытынды, аудармадағы баламалылық бастапқы тілдегі мәтін мен аударма тіліндегі мәтіндердің сәйкестігі қалыптасқан кезде пайда болады.

Жалпы аударманың негізгі екі концепциясы бар: лингвистикалық және әдебиеттану ғылымы. Аударма және аударматану бойынша негізгі екі мәселе шеңбері бар.

Бірінші мәселе шеңбері - бұл аудару шекараларының мәселелері, яғни мәтінді аудару мүмкіндігімен байланысты мәселелер.

Екінші мәселе шеңбері, біріншісімен арақатынасын белгілейтін және ерекше сипаттамасы бар аудару барабарлығымен байланысты мәселелер. Осы екі мәселелер шеңбері және олардың шешімі аударудың нормативті негізін белгілейді.

Аударма нормалары аудару актісінің ерекшелігін анықтайды. Яғни аударма үдерісі кезінде аудармашының дербестігі, тәуелсіздігі қай деңгейде екені байқалады.

Қазіргі кезде дербес емес аудармалық іс және тәуелсіз аудармалық іс бар. Дербес емес аудармалық іс тираждауға жақынырақ, сондай-ақ іс аударма мәтініне өте тығыз байланыста болады (ресми-істі, ғылыми-техникалық құжаттарды қамтиды), ал тәуелсіз - бұл аудармашының белгілі бір дербестігін белгілейді (публицистикалық және әдеби мәтіндер). Қоғамдық істің басқа бір түрі сияқты, аударма да белгілі бір қоғамдық мұқтаждықтарды қанағаттандыратын қажеттілік [12].

Аударма теориясын зерттеу қашанда өз маңызын жойған емес. Аударма теориясының міндеті - шығарманың түпнұсқамен аудармасының арасындағы ара қатынастардың заңдылықтарындағы ізін табу, аударманың жеке элементтерін барлап байқаудан туған тұжырым, қағидаларды ғылыми негізге сүйеніп қорытын- 
дылау және аударма практикасына көмек көрсететін, аудармашыға себін тигізетін межені белгілеп беру. Сонымен аударма теориясының негізгі зерттейтін объектісі - түпнұсқа мен аударманың арасындағы ара қатынас және оны пайымдау мен қорытындылауды керек ететін нақты жайларға көшкен формаларының айырмашылығы. Белгілі аудармашы ғалым Ә. Сатыбалдиев балама аударма жөнінде: «Аудару үстінде жеке сөздерге балама іздеу арқылы әрдайым ана тілінің бүкіл қазынасы аударылып-төңкеріліп отырады. Соның арқасында тіл қазынасының қалтарыстарындағы не бір байырғы сөздер, кейде тіпті, ұмытылып бара жатқан атаулар да жазу, сөйлеу қызметіне жегіледі де, әдеби тілдің тұлғасы болып шыға келеді. Аудару үстінде жеке сөздерге балама іздеу арқылы архаизм деп аталатын, яғни ескіріп бара жатқан көне сөздер жаңғырып, қазіргі жанды әдеби тіліміздің қатарына қосылып жатады. Олардың көбі бірте-бірте бұрынғы мәнін өзгертіп, жаңа мағынада қолданылады» $[1,7]$. Аударма жасауда балама сөздерді табу әдеби тіліміздің баюына да себеп болады.

Аударманың ауызша және жазба түрлері бар. Ауызша аударманың ізін ала аудару мен синхронды деген түрлері бар. Жазбаша аударманың негізгі үш түрі бар: еркін аударма, сөзбе-сөз және балама аударма. Біріншісі - еркін аударма, бұл тәсіл түпнұсқа тілін, әдеби ырғағын жетік білмеуден, түпнұсқаның өзіне тән ерекшелігін сақтаудан гөрі, аудармашының өзіне тиімділік жағын қарастырудан туады. Аудармадағы екінші әдіс - сөзбе-сөз аудару. Бұл тәсілді көбінесе оригиналдың тілін жақсы білетін аудармашылар қолданады, түпнұсқадан ауытқымайтын кемшіліктер осыдан туады. Үшінші тәсілі - балама аударма. Бұл - ең қиын түрі. Мұны екі тілді жетік білумен қатар, сол түпнұсқаның жан-жүрегін, ішкі сырын сарқа түсінетіндер қолданады. Оның үстіне аударманың бұл тәсіліне автордың стилін, жазу мәнерін, тіл мүсінін қалтқысыз, жете ұғынатындар ғана барады. Аудармада эквивалентті, балама, дәлме-дәл, сайма-сай, адекватты аударма сияқты терминдер семантикалық жағынан синонимдес болып келеді. «Кей тұстарда сөз болғалы отырған аталымдар теңбе-теңдік, дәлме-дәл аударма деген терминдермен теңбе-тең дәрежеде ұғынылады. Сондай-ақ балама дегендегі түпнұсқа тілдегі сөздің басқа тіл сөздігінде көрсетілген варианттары немесе аудару үдерісі кезінде түпнұсқадағы сөзге, тіркеске, фразаға, синтаксистік тұтастыққа тәржімашы аударылатын тілден таңдап, іріктеп алған мағынасы жуық нұсқалар деп түсініледі» $[2,39]$.
Аудару дәлдігі мәселесін филологтар бұрыннан бері қарастырып келе жатыр. Қазіргі кезде бұл мәселе әр түрлі аудармалық бағытта зерттелуде (Қазақстан мектебі: Г.И. Исина, А. Алдашева және т.б., Рессей мектебі: А.Т. Алексеева, В.Н.Комиссаров, Н.Р. Ткачев және т.б.). Жоғарыда аталған ғалымдар өз зерттеулерінде эквиваленттілік терминіне назар аударады.

Аударма түпнұсқаға абсолютті түрде дәл бола алмайды. Бірақ бұл тіл аралық коммуникация үшін бөгет емес. Л. К. Латышев «Айырмашылық болған кезде эквиваленттілік - бұл тілдің ең басты мәселесі және лингвистиканың түпкі мәселесі болып табылады. Аудармашы рецептор сияқты қызмет атқарады» деп жазады.

Бұдан басқа, «эквиваленттілік» терминімен бірге аударматануда «сәйкестілік» термині кең қолданылады. Берілген терминдер әр түрлі авторлардың жұмыстарыңда бір-бірін қайталап немесе әртүрлі категорияларды белгілеу үшін қолданылады. Я.М. Рецкер пікірінше, «эквивалент» - бұл тұрақты және тең мағыналы сәйкестілік, дағдыдағыдай, контекстке тәуелді болмайды. «Сәйкестілік» терминін қолдаған кезде, берілген зерттеуші лексикалық бірліктер арасындағы семантикалық сәйкестілік туралы айтады [3;10].

В.Н. Комиссаров бойынша, «аударманың эквиваленттілігі түпнұсқа мәтін мазмұнының және аудармасының барлық деңгейлерінің максималды ұқсастылығында жатыр». Сөйтіп, В.Н. Комиссаров бойынша эквиваленттілік Я.И. Рецкерге қарағанда кеңірек ұғым және ол аудару үдерісі кезінде берілген тілдің және аударылатын тілдің бірліктерінің үйлестіліктің бөлек түрін емес, негізгі мақсатын анықтайды [4].

Аударма толықтылығы (барабарлық) ұғымын дәлелдеуге тырыса отырып, А.В. Федоров толығырақ түсініктеме береді: «Аударманың толықтылығы - бұл түпнұсқада берілген мазмұн мағынасының толық жеткізілуі және аударманың түпнұсқаға функционалды-стилистикалық жағынан толық сәйкес келуі».

Аударманы қабылдаушының реакциясы берілген мәтіннің мазмұнын жеткізу мәселесімен байланысты. Ол қандай элементтерден тұратынын анықтау қажет. Л.К. Латышев А.Д. Швейцердің көзқарасын бөліп, келесі төрт элементтерді белгілейді:

1) заттық жағдайларды белгілеуімен байланысты денотативті мағына (яғни, заттық-логикалық);

2) пікір элементтерінің арасындағы синтаксистік (яғни, оның синтаксистік құрылымымен) байланысты белгілейтін синтаксистік мағына; 
3) функционалды-стилистикалық және экспрессивті бояумен белгіленген коннотативті мағына;

4) тілдік пікірдің және коммуникацияға түскен адамдардың қарым-қатынасымен анықталатын прагматикалық мағына [9; 53].

Я.И. Рецкер «Теория перевода и переводческая практика» деп аталатын еңбегінде баламалардың 4 түрін көрсетеді: толық, жартылай, абсолютті, қатыстық. Я.И. Рецкердің пікірінше, толық балама - бір мағыналы сөздің мағынасын толық жеткізетін балама, жартылай балама - аударылатын тілде түпнұсқа тілдің бірегей баламасы да, абсолютті балама - аударылатын тілдегі сөз түпнұсқа тілдегі сөзге мағыналық жағынан да, грамматикалық құрылымы жағынан да сәйкес балама, қатыстық балама - түпнұсқа тілі сөзінің жалпы мағынасын беретін, бірақ оның стильдік жағынан мағынасын толық ашпайтын балама [3].

Оның айтуы бойынша «балама» дегеніміз контексте тұрақты, тәуелсіз, теңбе-тең сәйкестік, ал, зерттеуші-ғалым А. Алдашеваның түсіндіруі бойынша, екітілді сөздікте берілетін нұсқалар А. Алдашева балама теориясы туралы Я. Рецкердің айтқан тұжырымдамасынан оның баламалық ұғымдарын дәл басып, тани қоймағандығын баса айтады. Ол: «балама аударма үдерісінің катализаторы, бұның әсіресе ауызша аудару үдерісі кезінде рөлі жоғары, өйткені сөздіктерде көрсеткен балама аудармашының санасына алдымен түседі де, контекстің мағынасын тез түсінуге ықпал етеді деп есептейді. Бірақ ғалым екітілді сөздіктер де дәл баламаны бере алмайтынын мойындай отырып, эквивалент дегендерге географиялық атауларды, жалқы есімдерді, терминдерді жатқызу керек деп санайды; ал басқа сөздер, сөз тіркестері баламалы сәйкестік деп танылуы тиіс; сондықтан толық балама, ішінара балама, абсолютті балама, шамалас балама типтес түрлерді ажырату қажет деген тұжырымдарға келеді» дейді [5;48].

Қазіргі таңда кейбір зерттеушілер «адекватный перевод» деген тіркесті «балама аударма» (А. Алдашева), «дәлме-дәл аударма», кейде аудармай «адекватты аударма» (Дуанина), «деңгейлестік аударма» (Ә.Тарақ), «эквивалент» ұғымын «саймасай» (Ж. Дадебаев пен С. Абдрахманов) деп аударып жүр. С. Абдрахманов «адекваттылықты» «барабар» деп атай отырып, оның саймасай аудармадан айырмашылығы «түпкі нәтижеге бағдар ұстайтындығында» деп көрсетеді [1; 48].

Жалпы, эквиваленттік түсінігін алғаш 1803 жылы Дж. Дальтон енгізген. Эквиваленттік (лат. aequalis - барабар, valentis - тепе-тең күші бар) деген мағынаны білдіреді. Ал, қазақ көркем аударматануында эквивалент ұғымы - балама ұғымымен түсіндіріледі. Балама аударма - жекелеген сөздер мен сөз тіркестерінің жай ғана теңбе-тең түсуі ғана емес, сондай-ақ, мағыналық жақтан, оқырманға әсер ету жағынан, тіпті дыбыстардың үндесуі жағынан, стиль жағынан да түпнұсқамен сайма-сай келетін аударма болуға тиіс. Балама аударма жасау үшін түпнұсқаның жан-жүрегін, ішкі сырын, авторды сарқа түсіну қажеттілігі сияқты талаптардың орындалуы қажет $[8 ; 36]$.

В.Н. Комиссаров қазіргі тәржіматануда аударма баламалылықтың анықтамасына үш түрлі көзқарас бар екенін көрсетеді:

- аударма баламалылық ұғымына бағалауыштық көзқарас: ең дұрыс аударма деп тек балама аударманы тану;

- аударма баламалылық ұғымына инвариантты көзқарас:

- түпнұсқа мазмұнында аударма баламалылығына жету үшін қажетті бір инвариант бөлігін табу;

- аударма баламалылық ұғымына эмпирикалық көзқарас:

- баламалылықтың негізін анықтау мақсатында көптеген аудармаларды олардың түпнұсқаларымен салыстыру [4].

Ғалымдардың көпшілігі төмендегідей түрлерін бөліп көрсетеді:

1) екі тілдегі жалпы ұғымдар аналог түрінде берілетін формалды баламалылық;

2) мағынасы бірдей ұғымды әртүрлі тәсілдермен беруге болатын мағыналық баламалық;

Бір жағдаят әртүрлі (мағыналық баламалылық кезіндегі сияқты) формалардың көмегімен ғана емес, сол формалар арқылы берілетін әртүрлі қарапайым мағыналардың көмегімен сипатталатын жағдаяттық баламалық.

Кейбір ғалымдар хабар алушыға белгілі бір нұсқау беруді қарастыратын прагматикалық баламалылықты бөліп көрсетеді.

Аударымдылық - бұл ықтималдық заңдылығы: егер аударманың барлық фактілерін жинақтап, талдау жасайтын болсақ, онда бастапқы және аударма мәтіндерінің коммуникативті-функционалды баламалылығы көп жағдайда жүзеге асатындығы белгілі болады. Сондықтан аударма баламалылығы - түпнұсқа мен аударма мазмұнының (мағыналық жақындық) бірлігі; балама аударма - бұл баламалықтың бір деңгейінде түпнұсқа мазмұнын жеткізетін аударма; баламалылық деңгейі (типі) - аударма ке- 
зінде сақталатын, түпнұсқа мазмұнымен анықталатын, түпнұсқа мен аударманың мағыналық жақындығының деңгейі. Потенциалды баламалылық пен аудармашылық баламалықты ажырата білу керек. Потенциалды баламалылық - екі әртүрлі тілде құрастырылған мәтін мазмұнының барынша мағыналық жақындығы. Аудармашылық баламалылық - аударма процесінде аудармашы қол жеткізген түпнұсқа мен аударма мәтіндерінің шынайы мағыналық жақындығы.

Баламалық ауыстырулар - мағыналары тірек сөзбен синонимдес келетін лексикалық функциялар. Тұтастай айтылған ойдың белгілі бір синтаксистік түрленуі барысында нақты бір мағынаны білдіретін сөз тірек сөздің орнына жұмсалуы мүмкін.

Жалған балама - екі түрлі тілдегі айтылуы жағынан ұқсас, бірақ мағынасы басқа сөздер. Жалған баламаларды аудармашының «жалған достары» деп те айтады. Бұл тіларалық омонимдер, яғни айтылуы мен жазылуы бірдей, бірақ беретін мағыналары әртүрлі болып келетін сөздер [4].

Аударманың баламалылығы - түпнұсқа мен аударма мазмұнының мағыналық жағынан жақындығы. Сондықтан аударма баламалылығының нормасы - аударманың түпнұсқаға барынша мағыналық жағынан сәйкес келуі. Баламалылық теориясы бастапқы мәтін мен аударылатын мәтіннің семантикалық қатынасын қарастырады.

Бастапқы және аударылған мәтіндердің баламалылығы мынадай үш шартты ескергенде ғана жүзеге асатын бастапқы мәтін мен аударылған мәтіннің тепе-теңдігі:

1. Аударылған мәтін бастапқы мәтіндей (түпнұсқа) адресатқа әсер етуі керек.

2. Аударылған мәтін барынша бастапқы мәтіннің мәтіндік аналогі болуы тиіс.

3. Аударылған мәтін бастапқы мәтін мазмұнынан, аудармашылық трансформация шеңберінен ауытқымауы керек [11].

Жалпы балама, баламалық мәселесіне аударматанушы ғалымдардың қай-қайсысы да соқпай өтпейді. Айталық, В. Виноградов “барабарлық- ты” дегенді барынша нақтылауға ұмтылды: “... под эквивлентностью в теории перевода следует понимать сохранение относительнего равенства содержательной, смысловой, семантической и функционально-коммуникативной информации, содержащейся в оригинале и переводе... слова и словосочетание перевода и оригинала, которые в однм из своих значений передают равный объем знаменителной информации и являются функционально равнозначными" $[6,17]$.

Балама - тілдік құралды тең мағынада, тең функцияда толық алмастыра алатын толық әлеуетке ие, тұрақты, екітілді лексикографиялық сөздіктерде норма ретінде ұсынылатын сөз тіркесі. Бұндай балама контекске тәуелсіз болады; сондықтан оны кейде тіларалық синоним деп те атайды. Таңбалардың, жеке сөздердің баламалылығы түпнұсқа мен аударама мәтіннің, олардың барлық сегменттерінің балама екендігіне дәлел бола алмайды. Мәтіннің бір-біріне балама болуы тілдік монифестация ауқымынан шығып, ұлттық мәдени фактілердің де балама болуын талап етеді. Түпнұсқадағы ақпаратқа, образға аударылатын тілден балама табу үшін синонимдердің образды, шеткергі сыңарлары іріктеліп алынады; аудармашы сондай-ақ функционалды қызметі бәсең тілдік бірліктерді түсіріп тастау немесе қосалқы элементтерді түсіндіру, мәтінді сегменттерге бөлу, әралуан трансформация әдісін қолдануға барады.

Қазақстан тәуелсіздігін алғалы бері тікелей түнұсқадан аударма мәселесі көтеріліп жатыр.

Аударманың адам қызметінің ең көне түрі екені белгілі. Әуел бастан аударма тілі басқа адамдардың бір-бірімен араласуына мүмкіндік тудырып, аса маңызды әлеуметтік қызмет атқарды және атқарып келеді. Жазбаша аудармалардың таралуы адамдарға басқа халықтардың мәдениетімен танысуына кең жол ашып, әдебиеттер мен мәдениеттердің араласып, баюына жағдай жасауда. Қазіргі кезде және алдағы уақытта да барабарлық аударма мәселесі әр түрлі аудармалық бағытта зерттеледі.

\section{Әдебиеттер}

1. Сатыбалдиев Ә. Рухани қазына. - Алматы: Жазушы, 1987.

2. Якобсон Р. О лингвистических аспектах перевода. - М., 1960.

3. Қазыбек Г. Аударма тәжірибесі: хрестоматия. - Алматы: Қазақ университеті, 2009.

4. Рецкер Я.И. Теория перевода и переводческая практика (Наше наследие). - Москва: Р.Валент, 2007.

5. Комиссаров В.Н. Современное переводоведение. - М.: ЭТС, 2002.

6. Алдашева А. Аударматану: лингвистикалық және лингвомәдени мәселелер. - Алматы, 1998.

7. Виноградов В.С. Введение в переводоведение. - М., 2001. 
8. Николаиди О.В. Понятие древности и эквивалентности при переводе различных торговых аннотаций с английского языка на русский // Научный Вестник №1. - 2002. - май.

9. Jeremy Munday. (2001). Introducing Translation Studies. Theories and applications. - London and New York: Routledge.

10. Edwin Gentzler. (1993). Contemporary Translation Theories. - London and New York: Routledge.

11. Диодимидова А. Русский Фауст: Когнитивные особенности переводческих трансформаций смысловой структуры оригинала // Русистика в СНГ. Отв. ред. Л.А. Вербицкая, В.Г. Костомаров - Златоуст, 2002.

12. Абдрахманова С. Өлең аудармасының теориясы мен поэтикасы. Автореферат. - Алматы: М.О. Әуезов атындағы әдебиет және өнер институты, 2007.

13. Кушанова Ж.О. Казахско-русско-немецкий художественные переводы / Автореферат - Астана: Евразийский национальный университет им. Л.Н. Гумилева, 2006.

14. Тер-Минасова С.Г. Язык и межкультурная коммуникация. - М.: Слово, 2000.

\section{References}

1. Satybaldiev A. Ruhani qasina. - Almaty: Jazushi, 1987.

2. Iacobson R. O lingvisticheskih aspectax perevoda, 1960.

3. Qazibek G.: «Audarma tajiribesi: xrestomatya. - Almaty: Qazaq universitety, 2009.

4. Retzker I.I. «Teoriya perevoda i perevodcheskaya practica (Nashe nasledie)». - Moskva: R. Valent, 2007.

5. Komissarov V.N. «Sovremennoe perevovedenie». - M.: ETC 2002.

6. Aldasheva A. «Audarmatanu: lingvistikalik jane lingvomadeni maseleler». - Almaty 1998.

7. Vinogradov V.C. Vedenie v perevovedenie. - M. 2001.

8. Nikolaidi O.V. Poniatie drevnosti i ekvivalentnosti pri perevode razlichnih torgovich annotazii c angliskogo iazika na ryski Nauchnii Vestnik. №1 - 2002. - may.

9. Jeremy Munday. (2001). Introducing Translation Studies, Theories and applications. - London and New York: Routledge.

10. Edwin Gentzler. (1993). Contemporary Translation Theories. - London and New York: Routledge.

11. Diodimidova A. Ruski faust: Kognitivnie osobennosty perevodcheskih transformasii smislovoy strukturi originala //Rusistika v SNG// otv. red. L.A. Verbizkaya V.G. Kostomarov. - Zlatoust, 2002.

12. Abdrahmanov C. olen audarmasinin teoriasy men poetikasy Avtoreferat. -Almaty M.O.Ayezov atyndagy adebiet jane oner instituty, 2007.

13. Kushanova J.O. Kazahsko-rusko-nemetski hudojestvenniye perevody Avtoreferat- Astana: Evraziski nazionalnii univresytet im. Gumileva L.N., 2006.

14. Ter-Minasova C.G. Iazik i mejculturnaya kommunikazia. - M.: Slovo, 2000. 